\title{
Improving the nutritional value of traditional finger millet porridges for children aged 7-24 months in Bujenje County of Western Uganda
}

\author{
Barugahara Evyline Isingoma ${ }^{1,2 \star}$, Mbugua Samuel ${ }^{1}$, Karuri Edward $^{1}$ and Gakenia Maina ${ }^{3}$ \\ ${ }^{1}$ Department of Food Science, Nutrition and Technology, University of Nairobi, Kenya. \\ 2Department of Human Nutrition and Home Economics, Kyambogo University, Uganda. \\ ${ }^{3}$ Regional Centre for Quality Health Care, Makerere University, Uganda.
}

Received 16 February, 2015; Accepted 3 August, 2015

\begin{abstract}
Child malnutrition is a major problem in Western Uganda where finger millet porridges are commonly used as complementary foods. This study aimed at improving the nutritional value and safety of finger millet porridges using Moringa oleifera, Cucurbita maxima and lactic acid fermentation. Proximate analysis, iron, zinc and vitamin A contents of composite flours was done according to AOAC methods while agar diffusion pouring technique and a seven point hedonic scale were used to analyse antimicrobial and organoleptic properties of the improved millet porridges, respectively. The porridges were developed with the aim of catering for at least $60 \%$ daily requirements for protein, vitamin $A$, iron and zinc for children aged 7-24 months. They were fermented using lactic acid starter cultures. Chisquare tests were used for comparing percentage acceptance of the porridges by mothers. Analysis of variance was carried out and differences among means were compared by Duncan's test at $p<0.05$. Fermented millet porridge with $7 \% \mathrm{M}$. oleifera leaves had the best nutrient composition and antimicrobial properties while fermented millet porridge with $17 \%$ C. maxima flesh was more acceptable by mothers. The porridges are thus a potential solution to inadequate nutrient intakes and diarrhoeal infections attributed to child malnutrition in Western Uganda and most developing countries.
\end{abstract}

Key words: Nutritional value, traditional millet porridges, western Uganda.

\section{INTRODUCTION}

Globally an estimated 165 million, 10 million and 52 million of children below five years of age are stunted, underweight and wasted, respectively (UNICEF, 2012). Micronutrient deficiencies of iron, vitamin A and zinc have also been reported as a major cause of death through diseases among these children, especially in developing countries (Black et al., 2008; West and Darnton-Hill, 2008; Bruno et al., 2005). In Uganda, 33\% of preschool children are stunted, $14 \%$ underweight, $5 \%$ wasted and $49 \%$ anaemic ( UBOS and ICF, 2012). Zinc deficiency is estimated to range between 20 to $69 \%$ while $20 \%$ are vitamin A deficient (Fanta, 2010). Most malnutrition in

${ }^{*}$ Corresponding author. Email: bisingoma@gmail.com. Tel: +256782673038.

Author(s) agree that this article remain permanently open access under the terms of the Creative Commons Attribution License 4.0 International License 
Uganda occurs during the period of complementary feeding (6-18 months) because of inappropriate complementary foods (UBOS and ICF, 2012). This is because of increased nutrient requirements for growth and development during this period but with limited gastric capacity (Compaore et al., 2011).

Critical stunting levels above 40\% have been persistently reported in Western Uganda where millet porridge is a common complementary food (Harvey et al., 2010; UBOS and ICF, 2001, 2012). Our baseline survey in this area revealed that stunting, underweight and wasting levels among children aged 7-36 months were 31,12 and $7 \%$, respectively. Poor complementary foods and diarrhoea were found to be major factors attributed to this poor nutritional status among children. About $25-77 \%$ of the children aged 7-24 months were found to be consuming less than recommended daily intake of energy, protein, vitamin A, iron and zinc with finger millet porridges as the most common bulky complementary food (unpublished data).

Finger millet porridge is recommended as a weaning food since it is one of the least allergenic, non acid forming and easy to digest cereal foods (Paragya and Raghuvanshi, 2012). However, it has low energy and nutrient density (Paragya and Raghuvanshi, 2012), limited amino acids (Usha and Lakshmi, 2010; Bachar et al., 2013) and high content of anti-nutrients such as phytates and tannins. These contribute to poor digestibility of protein and starch and reduce the overall availability of vitamins and minerals in millet (Lei, 2006; Paragya and Raghuvanshi, 2012). These shortcomings in finger millet porridges suggest inadequate dietary intake for children who use it as a main complementary food. There is need to improve on the nutrient density and utilisation of nutrients in this common feeding medium in Western Uganda. This can help to avoid the effects of malnutrition at such early ages which can result in irreversible damage to intellectual and physical development (Fanta, 2010). Moringa oleifera and Curcubita maxima powders are locally available food resources with a potential to bridge the nutritional value gap in finger millet and lower morbidity due to their antimicrobial properties (Dhiman et al., 2009; Fuglie, 2005; Usha and Lakshmi, 2010). Lactic acid fermentation is a potential household food preparation technology underutilized in Bujenje County but can also help abate the nutritional functional problems related to finger millet such as poor bioavailability of iron and zinc and low digestibility of starch and protein (Paragya and Raghuvanshi, 2012; Ogbe and Affiku, 2012). In addition, the antimicrobial properties in moringa and lactic acid fermentation can promote the safety and keeping quality of millet porridges (Ogbe and Affiku, 2012; Onyango et al., 2005). This is an advantage especially in such farming communities where porridges are kept for long before feeding the children. In Bujenje County, M. oleifera powders are mainly used as herbal concoction especially for children with diarrhoea. Alternatively, pumpkins are a popular crop whose leaves and fruits can be relied upon in times of scarcity. Therefore, the aim of this study was to improve on the nutritional value of finger millet porridges using locally available resources such as moringa (M. oleifera), pumpkin (C. maxima) and lactic acid fermentation in resource constrained and technologically under developed areas of Western Uganda.

\section{MATERIALS AND METHODS}

The experimental materials comprised of finger millet (Eleusine coracana), moringa ( $M$. oleifera) and pumpkin ( $C$. maxima) made into flour. A commonly used farmer's variety of finger millet known as 'Mugaali' was purchased from the local market, cleaned, dried and ground into flour. $M$. oleifera leaves and seeds were harvested, cleaned and dried indoors before being ground into flour by a local miller (mortar and pestle). A farmers' variety of C. maxima, identified as 'Okamanyaota' pumpkin was harvested when mature, washed, peeled and seeds removed. The flesh and seeds were sun dried for about 3-4 days before they were milled separately into flour.

\section{Nutrient quality analysis of finger millet, Moringa oleifera and Curcubita maxima foods}

Finger millet porridges consumed at baseline, finger millet flour and pumpkin (C. maxima) were analysed for proximate composition, zinc, iron and vitamin A contents in triplicates according to AOAC (2012). The Kjeldahl method (Jung et al., 2003) was used to determine the protein content $(\mathrm{N} \times 6.25)$ while fat was determined by solvent extraction (Sukhija and Palmquist, 1988). Carbohydrates were determined by the difference of the sum of all the proximate composition from $100 \%$. The calorific (energy) value was obtained by multiplying the value of carbohydrate, protein and crude fat by the Atwater factors of [energy content $=(\mathrm{g}$ carbohydrate $\times 4)+(\mathrm{g}$ fat $\times 9)+(g$ protein $\times 4$ ] (Papadopoulos et al., 1986). Iron and zinc were estimated using the atomic absorption spectrophotometer (AA 500 G., PG Instruments, Leicestershire, England) while vitamin A was determined by column chromatography (Parvin et al., 2014).

\section{Formulation of the porridge flours}

This was done basing on our baseline data. Study findings showed that in majority of children, only $40-50 \%$ of the daily requirements for kilo calorie, protein, vitamin A, iron and zinc were met by children's diets (unpublished data). Table 1 shows how these porridges were used to feed children in Bujenje County and the percentage of daily recommended nutrient intake (RNI) they covered in children aged 7-24 months. The average amount of porridge served to children varied from 150 to $300 \mathrm{ml}$ per day. Children were given porridges approximately 2 to 3 times a day (servings) depending on their age. The \% recommended nutrient intake (RNI) covered by these porridges was quite small and varied from zero to $55 \%$ depending on the nutrient and the age of the child.

The experimental porridge flours were developed using finger millet, C. maxima flesh and $M$. oleifera leaf flours, with the aim of providing at least $60 \%$ daily requirements for protein, iron, zinc and maximising vitamin $A$ in 150 to $300 \mathrm{ml}$ per serving of prepared porridges taken per day. Given that vitamin A content in millet flour was found to be almost zero, C. maxima (pumpkin) and M. oleifera 
Table 1. Nutrient intake from traditional millet porridges at baseline per day.

\begin{tabular}{|c|c|c|c|}
\hline Variable & 7-8 months & 9-11 months & $12-23$ months \\
\hline Serving amount & $150 \mathrm{ml}$ & $200 \mathrm{ml}$ & $300 \mathrm{ml}$ \\
\hline Amount of solids & $10 \mathrm{~g}$ & $15 \mathrm{~g}$ & $20 \mathrm{~g}$ \\
\hline Number of servings & $1.75 \pm 0.18$ & $2.65 \pm 0.06$ & $2.95 \pm 0.04$ \\
\hline \multicolumn{4}{|l|}{ Energy } \\
\hline $\mathrm{RNI}$ & $200 \mathrm{k} \mathrm{cal}$ & 300 k cal & $550 \mathrm{kcal}$ \\
\hline Total intake & $69.5 \mathrm{k} \mathrm{cal}$ & $157.8 \mathrm{k} \mathrm{cal}$ & $234.1 \mathrm{k} \mathrm{cal}$ \\
\hline$\%$ RNI covered & 35 & 53 & 42 \\
\hline \multicolumn{4}{|l|}{ Protein } \\
\hline RNI & $9.1 \mathrm{~g}$ & $9.6 \mathrm{~g}$ & $10.9 \mathrm{~g}$ \\
\hline Total intake & $1.6 \mathrm{~g}$ & 3.7 & 5.6 \\
\hline$\%$ RNI covered & 18 & 39 & 51 \\
\hline \multicolumn{4}{|l|}{ Vitamin A (RE) } \\
\hline RDA & $250 \mu \mathrm{g}$ & $300 \mu \mathrm{g}$ & $400 \mathrm{~g}$ \\
\hline Total intake & $0 \mu \mathrm{g}$ & $0 \mu \mathrm{g}$ & $0 \mu \mathrm{g}$ \\
\hline$\%$ RNI covered & 0 & 0 & 0 \\
\hline \multicolumn{4}{|l|}{ Iron } \\
\hline RDA & $11 \mathrm{mg}$ & $11 \mathrm{mg}$ & $11 \mathrm{mg}$ \\
\hline Total intake & $1.8 \mathrm{mg}$ & $4.0 \mathrm{mg}$ & $6.0 \mathrm{mg}$ \\
\hline$\%$ RNI covered & 16 & 36 & 55 \\
\hline \multicolumn{4}{|l|}{ Zinc } \\
\hline RDA & $2.8 \mathrm{mg}$ & $2.8 \mathrm{mg}$ & $2.8 \mathrm{mg}$ \\
\hline Total intake & $0.4 \mathrm{mg}$ & $0.9 \mathrm{mg}$ & $1.3 \mathrm{mg}$ \\
\hline$\%$ RNI covered & 14 & 32 & 46 \\
\hline
\end{tabular}

flours were formulated with finger millet flour at calculated rates of $300 \mu \mathrm{g}, 400 \mu \mathrm{g}$ and $500 \mu \mathrm{g}$ based on the daily recommendation for vitamin A for children aged 7-24 months (Brown and Dewey, 2003). Six complementary porridge flours (M1, M2, M3, P1 P2 and P3) were formulated as follows:

Flour 1 (M1): Finger millet: M. oleifera leaf powder (95: 5).

Flour 2 (M2): Finger millet: $M$. oleifera leaf powder (93: 7)

Flour 3 (M3): Finger millet: M. oleifera leaf powder (91: 9)

Flour 4 (P1): Finger millet: C. maxima flesh flour (88: 12)

Flour 5 (P1): Finger millet: C. maxima flesh flour (83: 17)

Flour 6 (P1): Finger millet: C. maxima flesh powder (79: 21)

The formulated porridges consisted of two versions (fermented or non-fermented) and were compared with the control of traditional millet porridges (fermented and non-fermented) to ascertain the effect of fermentation and $M$. oleifera leaves and $C$. maxima flesh flours on the porridges formulated.

\section{Fermentation of the formulated porridge}

The porridges were fermented using lactic acid fermentation starter cultures prepared according to U.K patent, ARIPO Patent No. AP122 (Mbugua, 1992). Formulated flours were each slurred with water (50\% solids), inoculated with $5 \%$ starter culture and incubated at room temperature for $24 \mathrm{~h}$. The $\mathrm{pH}$ and titratable acidity in the porridges were measured to determine if fermentation had occurred.

The $\mathrm{pH}$ was measured using Metrohm $605 \mathrm{pH}$ meter Swiss made, calibrated to 7.005. Ten millilitre samples of each of the porridges were put in a beaker. Five drops of $1 \%$ phenolphthalein solution were added and titration done to first persistent pink colour with $0.1 \mathrm{~N} \mathrm{NaOH}$. Titratable acidity was calculated on the basis of lactic acid equivalent according to the formula;

$\%$ lactic acid $=\underline{\text { nl alkali } \times \text { normality alkali } \times \text { relative molecular mass of lactic acid }}$ Weight of sample in grams

\section{Preparation of porridges}

Fourteen types of porridges were prepared on the day of the test. They included the control of traditional millet porridge fermented and non-fermented and porridges with different amounts of $M$. oleifera and C. maxima (pumpkin) flours. $200 \mathrm{ml}$ of smooth slurries made from $10-20 \%$ flour solids were mixed with $1 \mathrm{~L}$ of boiling water in cooking pots and the mixture stirred for at least $10 \mathrm{~min}$ to obtain smooth textured porridges. To ensure a comparable consistency in 
porridges, the total amount of water, flour and cooking time were adjusted for each of the porridge through visual examination by checking the fluidity of the porridge. The cooked porridges were kept in plastic jugs to maintain the serving temperature and sweetened before tasting.

\section{Sensory evaluation}

According to Gomiero et al. (2003) organoleptic parameters such as colour, aroma, taste, consistency and appearance are key measures of product quality (Compaore et al., 2011). Porridge samples from the different formulations were subjected to sensory evaluation using a seven point hedonic scale of 1-7, where $1=$ dislike very much; 2 = dislike moderately; 3 = dislike slightly; $4=$ neither like, nor dislike; 5 = like slightly; $6=$ like moderately and $7=$ like very much (Carpenter et al., 2000). Twenty two (22) mother panellists from Bujenje County were used to evaluate the formulated porridges in terms of colour, consistency, flavour, taste and overall acceptability. Twenty two (22) mother panellists aged 22-35 years with children less than two years of age were used because they determine the choice for children's feeds and were familiar with millet porridges. Each judge was presented with 7 disposable cups containing different blinded porridge samples per day for two days. The porridges were provided at the interval of 510 minutes. On the first day non-fermented moringa and pumpkin fortified millet porridges, and ordinary millet porridge as control, were presented while on the second day, fermented millet based porridges were presented. In addition, spoons for evaluating each porridge sample and bottled water for rinsing of the mouth in between testing of the porridges were provided. Rinsing the mouth minimised the carry-over taste effects from previous sample. Each treatment was evaluated three times by each panellist. The most acceptable porridges were standardized by a Bostwick Consistometer (Mouquet et al., 2006) and their nutrient composition analysed.

\section{Viscosity of the acceptable formulated porridges}

For this study $100 \mathrm{~g}$ finger millet flour, $150 \mathrm{~g}$ finger millet with $7 \% \mathrm{M}$. oleifera fortificant and $120 \mathrm{~g}$ finger millet with $17 \%$ C. maxima flour were mixed separately with $1000 \mathrm{ml}$ of clean tap water. They were brought to boil and simmered for at least 10 min while stirring to ensure a smooth consistency for porridges. The porridges were cooled to $40^{\circ} \mathrm{C}$, the recommended temperature for young children. The flow distance of the porridges was measurement by a Bostwick consistometer in triplicate (Mouquet et al., 2006).

\section{Determination of antimicrobial properties}

Antimicrobial properties of the porridges were determined over a 24 period to gauge the extent to which microorganisms could be resisted in formulated porridges. Agar diffusion pouring technique was used to monitor growth of pathogens on selective media by measuring the zones of inhibition against diarrhoea causing bacteria of E. coli, S. shiga, S. aureus and S. typhi (Doughari et al., 2007). These bacterial cultures were sourced from the Department of Public Health, Bacteriology and Toxicology, University of Nairobi, Kenya. Their turbidity was standardised to 0.39 optical densities before being inoculated in the media.

\section{Determination of growth of bacteria by plate count technique}

The growth of pathogens was monitored during the $24 \mathrm{~h}$ using selective media at $35^{\circ} \mathrm{C}$. Baird- Parker was used to monitor growth of $S$. aureus, Violet Red Bile Agar for E. coli, Brilliant green agar for S. typhi, and MacConkey agar for S. shiga. The media were each prepared aseptically in McCarthey bottles and put in a water bath at $45^{\circ} \mathrm{C}$. About $15-20 \mathrm{ml}$ media was poured on the PCA plate after being mixed with 0.2 millilitres of each of the standardised diluted bacteria pathogens and allowed to set. Three points were marked and holes $1 \mathrm{~cm}$ in diameter made using a cork borer in each of the plates equidistant from each other. Fermented porridges of finger millet, millet with $7 \%$ M. oleifera leaf powder and millet with $17 \% \mathrm{C}$. maxima flesh flour were each prepared and immediately cooled to $40^{\circ} \mathrm{C}$. About $0.2 \mathrm{ml}$ of each of the prepared porridges were put in each hole. The plates were left for about 15 min to allow for setting before being incubated at $35^{\circ} \mathrm{C}$ for $24 \mathrm{~h}$. The diameter of a colonyfree halo around the porridges was taken as a measure of the degree of antibacterial activity of the porridges.

\section{Data analysis}

Version 20 SPSS Inc., Chicago, IL was used for data analysis. Chisquare tests were used for comparing percentage acceptance of the porridges by mothers. Analysis of variance was carried out and differences among means were compared by Duncan's test at $\mathrm{p}<0.05$.

\section{RESULTS}

\section{Nutrient composition of finger millet, Cucurbita maxima and Moringa oleifera}

Table 2 shows the results for proximate and micronutrient composition of finger millet, C. maxima (flesh and seeds) and $M$. oleifera (leaves and seeds) flours. Finger millet flour had the highest carbohydrate content while $C$. maxima had the highest amounts of moisture. The seeds of both $M$. oleifera and $C$. maxima contained higher amounts of protein, energy and zinc compared to the leaves and flesh. There was more vitamin $A$ and ash (minerals) in C. maxima flesh and $M$. oleifera leaf powders than in their seeds.

\section{The $\mathrm{pH}$ and titratable acidity in the porridges}

Table 3 shows the $\mathrm{pH}$ and titratable acidity in the porridges. The $\mathrm{pH}$ and titratable acidity were significantly higher in fermented C. maxima fortified millet porridge.

\section{Organoleptic properties of the nutritionally optimised millet porridges}

Percentage acceptance of nutritionally optimised finger millet porridges by mother panelist compared with traditional finger millet porridge is shown in Table 4. Majority of the mothers preferred the flavour of fermented porridges to non-fermented porridges. Mothers also showed higher preferance in taste, colour and acceptability of fermented $M$. oleifera and $C$. maxima fortified finger millet porridges than the non-fermented. Addition of $9 \% M$. oleifera leaf powder and $21 \% C$. maxima flesh flours in finger millet porridges resulted in 
Table 2. Proximate and micronutrient composition of millet, pumpkin and moringa.

\begin{tabular}{lccccc}
\hline Variable & Pumpkin flesh & $\begin{array}{c}\text { Pumpkin } \\
\text { seeds }\end{array}$ & $\begin{array}{c}\text { Millet } \\
\text { flour }\end{array}$ & $\begin{array}{c}\text { Moringa } \\
\text { seeds }\end{array}$ & $\begin{array}{c}\text { Moringa } \\
\text { leaves }\end{array}$ \\
\hline Proximate composition & & & & & \\
Moisture \% & $10.99 \pm 0.01$ & $5.4 \pm 0.20$ & $10.44 \pm 0.02$ & $3.65 \pm 0.03$ & $7.56 \pm 0.02$ \\
Protein \% & $13.73 \pm 0.03$ & $23.12 \pm 0.06$ & $9.42 \pm 0.02$ & $23.26 \pm 0.10$ & $21.03 \pm 0.07$ \\
Fat/oil \% & $1.09 \pm 0.09$ & $26.51 \pm 0.01$ & $1.44 \pm 0.04$ & $26.00 \pm 0.20$ & $6.45 \pm 0.05$ \\
Fibre \% & $7.08 \pm 0.1$ & $32.68 \pm 0.02$ & $4.51 \pm 0.08$ & $24.95 \pm 0.02$ & $10.57 \pm 0.10$ \\
Ash \% & $7.57 \pm 0.10$ & $3.96 \pm 0.02$ & $2.58 \pm 0.04$ & $4.33 \pm 0.03$ & $11.10 \pm 0.05$ \\
Carbohydrates \% & $70.53 \pm 0.10$ & $23.34 \pm 0.30$ & $82.07 \pm 0.02$ & $23.44 \pm 0.22$ & $51.16 \pm 0.04$ \\
Energy $(\mathrm{kcal})$ & $346.88 \pm 0.10$ & $424.23 \pm 0.4$ & $375.99 \pm 0.99$ & $420.77 \pm 0.77$ & $332.15 \pm 0.15$ \\
& & & & & \\
Micro nutrient & & & & \\
Vitamin A $(\mu \mathrm{g} / 100 \mathrm{~g})$ & $2705.88 \pm 0.08$ & $126.85 \pm 0.8$ & $0.02 \pm 0.03$ & $268.13 \pm 0.13$ & $6076.37 \pm 0.70$ \\
Iron $(\mathrm{mg} / 100 \mathrm{~g})$ & $8.34 \pm 0.10$ & $8.71 \pm 0.03$ & $10.18 \pm 0.18$ & $7.51 \pm 0.51$ & $12.44 \pm 0.44$ \\
Zinc $(\mathrm{mg} / 100 \mathrm{~g})$ & $2.19 \pm 0.19$ & $8.54 \pm 0.54$ & $1.33 \pm 0.03$ & $4.65 \pm 0.65$ & $2.50 \pm 0.10$ \\
\hline
\end{tabular}

Results are mean \pm standard deviation, $n=3$.

Table 3. The $\mathrm{pH}$ and titratable acidity (\%) in fermented porridges.

\begin{tabular}{lcccc}
\hline Variable & Millet -porridge & Millet -pumpkin & Millet- moringa & P-value \\
\hline $\mathrm{pH}$ & $3.57 \pm 0.006$ & $3.46 \pm 0.012$ & $3.64 \pm 0.12$ & 0.000 \\
Titratable acidity & $0.095 \pm 0.002$ & $0.091 \pm 0.006$ & $0.100 \pm 0.006$ & 0.002 \\
\hline
\end{tabular}

Results are mean \pm standard deviation, $\mathrm{n}=3$.

Table 4. Acceptance of experimental porridges compared with traditional millet porridges in percentages.

\begin{tabular}{lcccccccccccc}
\hline \multirow{2}{*}{ Porridge } & \multicolumn{3}{c}{ Colour } & \multicolumn{3}{c}{ Taste } & \multicolumn{3}{c}{ Flavour } & \multicolumn{3}{c}{ Acceptability } \\
\cline { 2 - 13 } & C5 & C6 & C7 & T5 & T6 & T7 & F5 & F6 & F7 & A5 & A6 & A7 \\
\hline F1 & 18.2 & 27.3 & 54.5 & 18.2 & 31.8 & 50.0 & 22.7 & 45.5 & 31.8 & 22.7 & 27.9 & 49.4 \\
FF1 & 13.6 & 39.8 & 46.6 & 18.9 & 33.7 & 47.4 & 22.0 & 45.2 & 32.8 & 28.2 & 31.2 & 40.6 \\
F3 & 31.8 & 45.5 & 22.7 & 23.6 & 42.8 & 33.6 & 28.0 & 49.0 & 23.0 & 27.7 & 36.4 & 35.9 \\
FF3 & 13.6 & 50 & 36.4 & 21.0 & 41.8 & 37.2 & 24.6 & 43.0 & 32.4 & 27.3 & 35.9 & 36.8 \\
F6 & 18.2 & 31.2 & 50.6 & 18.0 & 37.8 & 44.2 & 13.7 & 45.5 & 40.8 & 22.2 & 37.3 & 40.5 \\
FF6 & 16.7 & 29.7 & 53.6 & 15.0 & 37.7 & 47.3 & 18.4 & 39.8 & 41.8 & 18.2 & 34.3 & 47.5 \\
\hline
\end{tabular}

7= Like very much; $6=$ like moderately and $5=$ =ike slightly. F1= Traditional millet flour, FF1=Fermented traditional millet flour, F3 $=$ millet with $7 \%$ moringa leaf, $F F 3=$ Fermented millet with $7 \%$ moringa leaf; $F 6=$ millet with $17 \%$ curcurbita flesh powder and FF6 $=$ Fermented millet with $17 \%$ curcurbita flesh powder.

less desired porridges in colour and overall acceptability.

\section{Viscosity of acceptable porridges}

The viscosities of the experimental porridges and traditional millet porridge are shown in Table 5 below. Finger millet porridges fortified with $M$. oleifera leaves had the highest amounts of flour solids and yet with the highest flow distance. The flow distance of traditional millet porridge was very low and yet it had the lowest amount of solid matter. The amount of flour solids in fermented and non-fermented porridges did not differ much. There was some difference in amounts of flour solids in fermented $C$. maxima fortified finger millet porridge compared with the non-fermented.

\section{Nutrient composition of organoleptically acceptable millet based porridges}

Table 6 shows the nutrient composition of organoleptically accepted ready to use finger millet based porridges compared with the non-fermented finger millet 
Table 5. Viscosity of porridges at $40^{\circ} \mathrm{C}$.

\begin{tabular}{|c|c|c|}
\hline Porridge sample & $\begin{array}{c}\text { Amount of flour solids } \\
/ 100 \mathrm{ml} \text { porridge }(\mathrm{g})\end{array}$ & Flow distance \\
\hline Ordinary millet porridge & 10 & $117 \pm 1.0$ \\
\hline Fermented millet porridge & 11 & $117 \pm 2.0$ \\
\hline Non fermented millet pumpkin porridge & 11 & $118 \pm 2.0$ \\
\hline Fermented millet pumpkin porridge & 13 & $119 \pm 1.5$ \\
\hline Non-fermented millet moringa porridge & 15 & $121 \pm 2.0$ \\
\hline Fermented millet moringa porridge & 15 & $122 \pm 2.0$ \\
\hline
\end{tabular}

Table 6. Nutrient composition of organoleptically acceptable millet based porridges.

\begin{tabular}{|c|c|c|c|c|c|c|c|}
\hline Nutrient & $\mathrm{F} 1$ & FF1 & F3 & FF3 & F6 & FF6 & $\begin{array}{l}\text { Recommended } \\
\text { value }(\mathrm{g})^{*}\end{array}$ \\
\hline Carbohydrates (g/100 g DM) & $81.61 \pm 0.61^{a}$ & $81.06 \pm 0.06^{a}$ & $79.67 \pm 0.20^{a}$ & $79.61 \pm 0.3^{a}$ & $79.91 \pm 0.01 \mathrm{a}$ & $79.85 \pm 0.02^{a}$ & $64 \pm 4$ \\
\hline Protein (mg/100 g DM) & $9.24 \pm 0.10^{a}$ & $9.34 \pm 0.10^{a}$ & $10.25 \pm 0.27^{b}$ & $10.37 \pm 0.30^{b}$ & $10.01 \pm 0.17^{\mathrm{ab}}$ & $10.15 \pm 0.15^{b}$ & $\geq 15$ \\
\hline Energy (kcal/100 g DM) & $396.86 \pm 0.85^{a}$ & $401.39 \pm 0.34^{b}$ & $402.02 \pm 0.20^{b}$ & $406.10 \pm 0.10^{c}$ & $396.28 \pm 0.10^{a}$ & $396.61 \pm 0.10^{a}$ & $400-426$ \\
\hline \multicolumn{8}{|l|}{ Micronutrients } \\
\hline Vitamin $\mathrm{A}(\mu \mathrm{g} / 100 \mathrm{~g})$ & $0.001 \pm 0^{a}$ & $0.003 \pm 0^{a}$ & $333.3 \pm 0.30^{d}$ & $329.20 \pm 0.18^{e}$ & $312.8 \pm 0.08^{b}$ & $319.5 \pm 0.05^{c}$ & \\
\hline Iron $(\mathrm{mg} / 100 \mathrm{~g})$ & $10.13 \pm 0.10^{\mathrm{a}}$ & $10.33 \pm 0.10^{\mathrm{a}}$ & $17.92 \pm 0.20^{d}$ & $17.99 \pm 0.4^{c}$ & $9.80 \pm 0.01^{a}$ & $9.91 \pm 0.10^{\mathrm{a}}$ & 16 \\
\hline Zinc (mg/100 g) & $2.15 \pm 0.10^{b}$ & $2.21 \pm 0.10^{\mathrm{b}}$ & $3.20 \pm 0.20 \mathrm{a}$ & $3.37 \pm 0.10^{a}$ & $2.01 \pm 0.01^{b}$ & $2.32 \pm 0.10^{\mathrm{b}}$ & 3.2 \\
\hline
\end{tabular}

Recommended value reference: Codex alimentarius reference (ljarotimi and Keshinro 2012), Values are the means of triplicate determinations expressed on dry weight basis. F1= Traditional millet flour, FF1=Fermented traditional millet flour, F3 = millet with $7 \%$ moringa leaf, FF3= Fermented millet with 7\% moringa leaf; F6=millet with 17\% curcurbita flesh powder and FF6= Fermented millet with $17 \%$ curcurbita flesh powder.

based porridges. $M$. oleifera fortified porridges were superior in energy, protein, zinc, vitamin $A$ and iron content when compared with all porridges. C. maxima fortified finger millet porridges were better than traditional millet porridge in protein, vitamin $\mathrm{A}$ and zinc contents. Only moringa fortified porridges could meet the iron, zinc and energy recommendations of the CODEX Alimentarus Guidelines on formulated supplementary foods. There were some slight increases in energy, protein, vitamin A, iron and zinc contents after fermentation. However the carbohydrate content slightly reduced.

\section{Expected nutrient intake from improved millet porridges basing on baseline data and WHO guidelines}

Table 7 shows the number of servings, amount per serving, amount of solids in the serving, cost of the porridges per day and the \% RNI expected to be met by the porridges. After adjusting on the viscosity and the expected number of porridge servings per day basing on WHO guidelines for infant feeding, traditional millet porridges showed the potential of catering for $\geq 60 \%$ energy requirements in children aged 7-24 months. However, the iron and zinc gaps still remained especially for children aged 7-11 months. Traditional millet porridges still have a big challenge of catering for vitamin A requirements. Finger millet porridges fortified with $M$. oleifera and $C$. maxima have the potential of meeting $\geq$ $60 \% \mathrm{RNI}$ for energy, protein, vitamin $\mathrm{A}$, iron and zinc in Bujenje County of Western Uganda. The porridges all costed less than $\$ 1$ per day and there were no significant difference in their prices.

\section{Antibacterial activity of the porridges}

The diameters of inhibition halos against test pathogens of E. coli, S. aureus, S. typhi and S. shiga are shown in Table 8. All porridges offered some resistance against tested diarrhoea pathogens. Fermented $M$. oleifera fortified finger millet porridges offered the best inhibition against test pathogens of $E$. coli, $S$. shiga and $S$. typi while fermented $C$. maxima fortified finger millet porridge and fermented millet porridges mostly resisted $S$. aureus.

Diameter inhibition halos showed $S$. aureus as the most inhibited by all the porridges and $S$. typhi as the 
Table 7. Nutrient intake from improved millet porridges compared basing on baseline data and WHO guidelines.

\begin{tabular}{|c|c|c|c|}
\hline Variable & 7-8 months & 9-11 months & 12-23 months \\
\hline \multicolumn{4}{|l|}{ Serving } \\
\hline Number of servings & 4 & 3 & 3 \\
\hline Amount of serving & $150 \mathrm{mls}$ & $200 \mathrm{mls}$ & $300 \mathrm{mls}$ \\
\hline \multicolumn{4}{|l|}{ Amount of solids } \\
\hline Traditional millet & $15 \mathrm{~g}$ & $20 \mathrm{~g}$ & $30 \mathrm{~g}$ \\
\hline Cucurbita fortified & $18 \mathrm{~g}$ & $25 \mathrm{~g}$ & $35 \mathrm{~g}$ \\
\hline Moringa fortified & $20 \mathrm{~g}$ & $30 \mathrm{~g}$ & $40 \mathrm{~g}$ \\
\hline \multicolumn{4}{|l|}{ Cost per day } \\
\hline Traditional millet & $\$ 0.02$ & $\$ 0.02$ & $\$ 0.04$ \\
\hline Cucurbita fortified & $\$ 0.03$ & $\$ 0.03$ & $\$ 0.04$ \\
\hline Moringa fortified & $\$ 0.03$ & $\$ 0.03$ & $\$ 0.05$ \\
\hline Energy (RNI) & $200 \mathrm{k} \mathrm{cal}$ & 300 k cal & $550 \mathrm{k} \mathrm{cal}$ \\
\hline Traditional millet & $238.1 \mathrm{kcal}(119)$ & $238.1 \mathrm{k} \mathrm{cal}(79)$ & $357.1 \mathrm{k} \mathrm{cal}(64)$ \\
\hline Cucurbita fortified & $285.6 \mathrm{kcal}(143)$ & 297.5 k cal (99) & $416.4 \mathrm{k}$ cal $(76)$ \\
\hline Moringa fortified & 324.9 kcal (162) & 365.5 k cal (122) & $487.3 \mathrm{k} \mathrm{cal}(89)$ \\
\hline Protein (RNI) & $9.1 \mathrm{~g}$ & $9.6 \mathrm{~g}$ & $10.9 \mathrm{~g}$ \\
\hline Traditional millet & $5.5 \mathrm{~g}(61)$ & $5.5 \mathrm{~g}(58)$ & $8.3 \mathrm{~g}(76)$ \\
\hline Cucurbita fortified & $7.2 \mathrm{~g}(80)$ & $7.6 \mathrm{~g}(79)$ & $10.7(98)$ \\
\hline Moringa fortified & $8.3 \mathrm{~g}(91)$ & $9.3 \mathrm{~g}(97)$ & $12.4 \mathrm{~g}(114)$ \\
\hline Vitamin A (RNI) & $250 \mu \mathrm{g}$ & $300 \mu \mathrm{g}$ & $400 \mu \mathrm{g}$ \\
\hline Traditional millet & $0.002 \mu \mathrm{g}(0)$ & $0.002 \mu \mathrm{g}(0)$ & $0.003 \mu \mathrm{g}(0)$ \\
\hline Cucurbita fortified & $230.0 \mu \mathrm{g}(92)$ & $234.4 \mu \mathrm{g}(78)$ & $328.1(82)$ \\
\hline Moringa fortified & $263.4 \mu \mathrm{g}(105)$ & $296.3 \mu \mathrm{g}(98)$ & 395.16 (99) \\
\hline Iron $^{*}$ & $11 \mathrm{mg}$ & $11 \mathrm{mg}$ & $11 \mathrm{mg}$ \\
\hline Traditional millet & $6.0 \mathrm{mg} \mathrm{(55)}$ & $6.0 \mathrm{mg} \mathrm{(55)}$ & $9.1 \mathrm{mg}(83)$ \\
\hline Cucurbita fortified & $7.1 \mathrm{mg}(65)$ & 8.9 mg (96) & $11.9 \mathrm{mg}(108)$ \\
\hline Moringa fortified & $14.4 \mathrm{mg}(131)$ & $16.2 \mathrm{mg}(147)$ & $21.6 \mathrm{mg}(196)$ \\
\hline Zinc $^{* *}$ & $2.8 \mathrm{mg}$ & $2.8 \mathrm{mg}$ & $2.8 \mathrm{mg}$ \\
\hline Traditional millet & $1.3 \mathrm{mg} \mathrm{(46)}$ & $1.3 \mathrm{mg} \mathrm{(46)}$ & $1.9 \mathrm{mg}(69)$ \\
\hline Cucurbita fortified & $1.7 \mathrm{mg}(60)$ & $2.0 \mathrm{mg}(62)$ & $2.7 \mathrm{mg}(99)$ \\
\hline Moringa fortified & $2.0 \mathrm{mg}(96)$ & $3.0 \mathrm{mg}(108)$ & $4.0 \mathrm{mg}(144)$ \\
\hline
\end{tabular}

Iron* Assuming medium iron bioavailability (10\%). Zinc** Assuming moderate bioavailability (30\%) References: World Health Organisations Recommendations (Dewey and Brown 2002; Ruel, Loechl, and Pelto 2004).Numbers in brackets represent $\%$ RNI met. Curcurbita fortified $=17 \%$ curcurbita maxima; Moringa fortified $=7 \%$ moringa oleifera

most resistant tested pathogen in all porridges.

\section{DISCUSSION}

\section{Nutrient composition of the raw materials used in the formulation}

Studies have reported carbohydrate content of $79.5 \%$, iron content of $9.9 \mathrm{mg} / 100 \mathrm{~g}$ flour and crude fibre content of $4.8 \%$ in finger millet which are very close to the present study findings (Bachar et al., 2013; Obilana, 2003; Paragya and Raghuvanshi, 2012). The protein content in this study is within the reported of $5.6-12.7 \mathrm{mg}$ by Paragya and Raghuvanshi (2012) while the fat content is within 1.3-1.8 g reported by Bachar et al. (2013).

Present study findings on ash and zinc content of finger millet are also within $1.7-4.13 \mathrm{mg}$ and $0.92-2.55 \mathrm{mg}$ per $100 \mathrm{~g}$ finger millet flour, respectively reported (Amadou et al., 2013; Bachar et al., 2013). Gopalan et al. (1999) have 
Table 8. Diameters of inhibition halos (mm) for microorganisms in fermented porridges.

\begin{tabular}{llll}
\hline Variable & FF1 & FF3 & FF6 \\
\hline E. coli halo size & $0.93 \pm 0.03$ & $1.03 \pm 0.09$ & $1.33 \pm 0.12$ \\
S. aureus halo size & $1.00 \pm 0.06$ & $1.33 \pm 0.09$ & $1.27 \pm 0.19$ \\
S. typhi halo size & $0.37 \pm 0.09$ & $0.43 \pm 0.08$ & $0.53 \pm 0.18$ \\
S. shiga halo size & $0.53 \pm 0.18$ & $0.53 \pm 0.18$ & $1.100 \pm 0.15$ \\
\hline
\end{tabular}

Results are mean \pm standard deviation, $\mathrm{n}=3$; FF1= Fermented millet porridge; FF3 = Fermented millet-moringa porridge (7.12 g moringa fortificant $/ 100 \mathrm{~g}$ flour); $\mathrm{FF} 6=$ Fermented millet-pumpkin porridge (16.61 g moringa fortificant $/ 100 \mathrm{~g}$ flour).

reported $45 \mu \mathrm{g}$ carotene per $100 \mathrm{~g}$ of finger millet while nap.edu reported 6 retinol equivalent (Paragya and Raghuvanshi, 2012). Present study findings concur with Bhaskaracharya (2001) reports of finger millet being a very poor source of $\beta$-carotene with values ranging from 0 to $1 \mu \mathrm{g} / 100 \mathrm{~g}$ (Paragya and Raghuvanshi, 2012).

Results for Moringa oleifera leaves compare closely with findings by Ogbe and Affiku (2012) but contrast for zinc and energy content in moringa leaves. Ogbe and Affiku (2012) reported $6.0 \mathrm{mg}$ of zinc and $1440 \mathrm{kcal}$ energy against $2.5 \mathrm{mg}$ zinc and $332.15 \mathrm{kcal}$ energy observed in the present study. Thierry et al. (2013) also reported protein content of 31.62-35.59 $\mathrm{g}$ and iron content of 20.34-33.68 mg which are quite higher than the present study findings.

$M$. oleifera seeds have been reported to vary in protein content from 29.63-31.36g, fat from 30.36-40.39, ash from 6-8 and 9\% carbohydrates (Compaore et al., 2011). However, the reported carbohydrate content is low compared to the present research findings of $23.44 \%$ while for protein, fat and ash contents, they are slightly higher. These differences in nutrient content may be attributed to differences in soils and stage of maturity of M. oleifera plants.

High moisture, carbohydrates and vitamin A levels and lower protein, fat/oil and zinc levels in the C. maxima flesh compared to the seed is comparable to findings by Mohammad (2004). Low moisture indicates good storage properties since growth of micro-organisms can be hindered. Findings in this study show lower levels of protein in C. maxima $(23.12 \mathrm{~g})$ compared to $36.2 \mathrm{~g}$ and $39.3 \mathrm{~g}$ reported by Mohammad (2004) and Fedha et al. (2010), respectively. Cucurbita flesh protein of $13.73 \mathrm{~g}$ was also different from the $4.0 \mathrm{~g}$ proteins reported by Fedha et al. (2010). However present findings concur with Usha and Lakshmi (2010) results for protein, fat and ash contents of $15.69 \mathrm{~g}, 1.62 \mathrm{~g}$ and $5.7 \mathrm{~g}$ respectively. According to Compaore et al. (2011), pumpkin seeds contain $42 \%$ protein, $13.4 \%$ carbohydrate, $42.9-57.3 \%$ lipids and $4.33-7.25 \%$ ash (minerals). These values are higher than the present study findings. The differences in nutrient composition can be attributed to the variety of pumpkin, nature of soils and maturity stage (Fedha et al., 2010).

High amounts of protein, energy and zinc in C. maxima and $M$. oleifera seeds compared to the leaf and flesh justify their suitability as good raw materials for promotion of high nutrient density diets in infant food formulation (Compaore et al., 2011). Fibre prevents constipation but high amounts of fibre in the seeds could be a challenge in infants diet since it causes irritation of the gut mucosa (Elinge et al., 2012; Mohammad, 2004). Though moringa and pumpkin seeds have more protein, fat/oil and energy than the leaf and flesh powders, they were not suitable for fortifying finger millet porridges. This was because of their comparatively low levels of vitamin A when compared to the leaves of moringa and pumpkin flesh and the fact that finger millet had almost no vitamin A. $M$. oleifera leaves and C. maxima (pumpkin) flour have very high amounts of vitamin $A$ which could be utilised in improving vitamin $A$ content in millet porridges. This would promote vitamin A intake in children, build body immunity and perhaps reduce on infections in children that are common in Bujenje County (Ring and Develo, 2009). The high iron content in moringa leaves could help address the iron deficiencies that are common among preschool children in Western Uganda.

\section{Effect of lactic fermentation, moringa and pumpkin fortificants on the organoleptic properties of the formulated porridges}

The reduction in acceptability of $21 \%$ Cucurbita maxima fortified finger millet porridges can be attributed to the yellow colour imparted by the carotenoids pigment naturally present in Cucurbita maxima (Usha and Lakshmi 2010). The dark green colour of the M. oleifera leaves was also responsible for the reduced acceptability in finger millet porridges with $9 \% M$. oleifera leaves powder. Pumpkin (Cucurbita) fortified millet porridges were more acceptable than moringa fortified because of being familiar foods. Higher preference for fermented products in terms of flavour can be attributed to the production of lactic acid, alcohols and carboxylic acids in fermented products that promote production of a variety of flavour of the existing food (Blandino et al., 2003; Lei, 2006). The oven temperatures slightly altered the colour in the process of drying. This could explain why majority of mothers preferred the colour of fermented M. oleifera and $C$. maxima fortified porridges to the non-fermented versions.

Effect of lactic fermentation, moringa and pumpkin flours on the nutrient content of the formulated porridges

M. oleifera leaf powder and C. maxima flesh powder were able to improve the nutrient content of finger millet 
porridges. Through optimisation of nutrients and costs, the nutrient content of the porridges was improved and the prices kept to the minimum. $M$. oleifera and $C$. maxima flesh flours had a negative impact on gelatisation of porridges compared to millet flours. This was also observed by Usha and Lakshmi (2010) when formulating weaning mix and was attributed to high pectin levels in Cucurbita. This property of a weaning mix is ideal because diets that form gel at higher concentrations allow dilution in attempts to increase the digestibility of the weaning mix without losing the density of nutrients as compared to weaning mixes with least concentration (Usha and Lakshmi, 2010). Such a property is especially vital for developing countries where low calorie and protein intake in children have been attributed to dilution of complementary foods (Hossain et al., 2005). Finger millet porridges fortified with $M$. oleifera powders resulted in more nutritious porridges within the recommended viscosity for children (Mouquet et al., 2006). Complementary porridge consistency has been reported to have considerable variation depending on character, size, proportion of suspended particles (Bruyeron et al., 2010). There was some decrease in carbohydrate content after fermentation since lactic acid bacteria use sugars during fermentation (Thierry et al., 2013). This decrease in carbon ration causes the nitrogen in fermented slurry to be concentrated and must have affected the total mass resulting in slight increases in energy, protein, vitamin A, iron and zinc in the fermented porridges (Onyango et al., 2005; Thierry et al., 2013).

Moringa fortified porridges had the best nutrient composition and were able to meet the energy, iron and zinc recommendations of the CODEX requirements. Scholars have shown the potential of moringa in improving child nutrition (Odinakachukwu et al., 2014; Thierry et al., 2013). Moringa has also demonstrated the potential of improving vitamin A in serum depleted rats (Thurber and Fahey, 2009). C. maxima fortified millet porridges had better protein, vitamin $A$ and zinc compared to traditional millet porridges. Consumption of pumpkins (Cucurbita) has been promoted as a means of promoting vitamin $\mathrm{A}$ intake among resource constrained populations (Dhiman et al., 2009). C. maxima has also demonstrated the potential of providing economic, nutritious and organoleptically acceptable weaning mix (Compaore et al., 2011; Usha and Lakshmi, 2010). Adequate processing and judicious blending of the locally available foods has been encouraged as a measure of improving intake of nutrients among children in areas with limited resources (Lombor et al., 2009).

\section{Antimicrobial properties of formulated millet porridges}

All lactic fermented porridges had some inhibition properties against bacterial pathogens. Lactic acid bacteria are reported to produce antimicrobial substances which inhibit certain diarrhoea causing microorganisms such as E. coli, salmonella typhi and shigella (GabrielAjobiewe et al., 2014; Guslandi, 2005). Efficient lactic acid fermentation is reported to produce a $\mathrm{pH}$ of 4 or less at which growth of pathogens is inhibited (Lei, 2006). This explains the better inhibition against $\mathrm{S}$. aureus observed in pumpkin (Cucurbita) fortified finger millet porridges with high titratable acidity. Other factors responsible for safety of fermented foods include production of bacteriocins, hydrogen peroxide, carbon dioxide, ethanol and antibiotic like substances (Gabriel-Ajobiewe et al., 2014; Lei, 2006). Presence of $M$. oleifera leaf powder in the finger millet porridge must have contributed to the larger halo size against $\mathrm{E}$. coli. Moringa also had better inhibitory characteristics against Shigella shiga and salmonella typhi. This is because of the complex chemical compounds such as kaempferol and rutin contained in $M$. oleifera leaves that have antioxidant and antibiotic properties (Patel et al., 2011; Fuglie, 2005). Moringa leaf extract is also reported to have exhibited broad spectrum activity against test organisms of $\mathrm{E}$. coli and S. typhi (Bukar et al., 2010). Bacteria inhibition in curcubita fortified porridges could also be attributed to photochemicals found in pumpkin (Dhiman et al., 2009). Inhibition of growth of bacteria in these porridges was therefore due to combined effects of lactic acid fermentation and presence of antioxidants in moringa and pumpkin powders (Dhiman et al., 2009; Patel et al., 2011). These antimicrobial properties of the formulated porridges justify them for use in communities like Bujenje County where high infection rate has been reported (Ring and Develo, 2009). Perhaps this would reduce on the high levels of diarrhoea infections that are common during the weaning period not only in Uganda but also in developing countries.

\section{Nutritional potential of improved millet based porridges}

Foods for infants should be energy dense because of the limited gastric capacity in young children coupled with the need for increased nutrient intake. The present recipe for traditional millet porridges if intergrated in the feeding practices of this local community and combined with nutritional education could address children's energy needs. However the iron and zinc gaps would still remain. These are very essential nutrients in young children whose effects cannot be neglected especially at this critical stage of growth and development. These results confirm the superiority of finger millet to other cereals in catering for energey needs of children (Obilana, 2003; Paragya and Raghuvanshi, 2012). They also reflect the need for enriching the content of vitamin $A$, iron and zinc in millet porridges to avoid long term effects of these micronutrients.

Experimental porridges have the potential of meeting 
the target point of $\geq 60 \% \mathrm{RNI}$ for children. The porridges were designed to be intergrated in the feeding practices of children aged 7-24 months and therefore could reduce malnutrition in Western Uganda. The formulated porridges are thus better complementary foods compared to traditional millet porridges. This is qualified not only by their increased nutrient content but also the antimicrobial properties they possess. Increased digestibility of starch and protein and bioavailability of iron and zinc are some of the benefits of lactic fermented millet porridges that have been reported by various scholars (Onyango et al., 2005; Lei, 2006). Lactic acid fermentation has also been reported to increase iron availability, gastric digestibility of protein and to reduce on the level of phytates in moringa powder (Thierry et al., 2013).

\section{Conclusion}

Formulation and fortification of millet porridges using locally available food resources and technologies can provide nutritious, cost effective and safe foods to prevent malnutrition. This is believed to be a practical food based approach aimed at combating malnutrition among infants and children in Western Uganda and other developing countries. However certain aspects like digestibility of macronutrients and bio-availability of vitamins and minerals in these formulated porridges need further investigation. The porridges can therefore be evaluated for their effectiveness among malnourished children in Bujenje County, Western Uganda.

\section{Conflict of interests}

The authors did not declare any conflict of interest.

\section{ACKNOWLEDGEMENT}

Source of funding: Kyambogo University, Uganda is hereby acknowledged for funding this project. The authors would also like to thank the parents/caretakers who willingly participated in this project and the Department of Public Health, Bacteriology and Toxicology, University of Nairobi which provided us with bacteria cultures.

\section{REFERENCES}

Amadou I, Mahamadou EG, Guo-Wei L (2013). Millets: Nutritional composition, some health benefits and processing-A review. Emir. J. Food Agric. 25 (7): 501-508

AOAC (2012). Association of Official Analytical Chemists (19th, Ed.). Official Method of Analysis. Washington DC

Bachar K, Mansour E, Ben Khaled A, Mabrouka A, Haddad M, BenYahya L, El-Jarray N, Ferchichi A (2013). Fiber content and mineral composition of the finger millet of the Oasis of Gabes Tunisia. J. Agric. Sci. 5 (2): 219.
Black RE, Allen LH, Bhutta ZA, Caulfield LE, de Onis M, Ezzati M, Mathers C, Rivera J; Maternal and Child Undernutrition Study Group (2008). Maternal and child undernutrition: global and regional exposures and health consequences. Lancet 371 (9608):243-260.

Blandino A, Al-Aseeri ME, Pandiella SS, Cantero D, Webb C (2003). Cereal-based fermented foods and beverages. Food Res. Int 36(6):527-543.

Brown KH, Dewey KG (2003). Update on technical issues concerning complementary feeding of young children in developing countries and implications for intervention programs. Food Nutr. Bull. 24 (1): 5-28.

Bruno BL, Danrton, Davidson F (2005). Report of a WHO/UNICEF/IAFE/IZINCG Interagency meeting on zinc status indicators IAEA Headquarters,Vienna. Food Nutr. Bull. 23 (3): 403429.

Bruyeron O, Denizeau M, Berger J, Trèche JS (2010). Marketing complementary foods and supplements in Burkina Faso, Madagascar, and Vietnam: Lessons learned from the Nutridev program. Food Nutr. Bull. 31 (Supplement 2): 154-167.

Bukar A, Uba A, Oyeyi T (2010). Antimicrobial profile of Moringa oleifera Lam. extracts against some food-borne microorganisms. Bayero J. Pure Appl. Sci. 3(1): 43 - 48.

Carpenter R, Lyon H, Hasdell A (2000). Guidelines for sensory analysis in food product development and quality control. $2^{\text {nd }} \mathrm{Ed}$. Maryland, USA: Aspen publishers INC.

Compaore WR, Nikièma PA, Bassole HIN, Savadogo A, Hounhouigan DJ (2011). Nutritional properties of enriched local complementary flours. Adv. J. Food Sci. Technol. 3(1): 31-39.

Dhiman A, Sharma K, Surekha A (2009). Functional constituents and processing of pumpkin. Food Sci. Technol. 46: 411-417.

Doughari JH, Pukuma MS, De N (2007). Antibacterial effects of Balanites aegyptiaca L. Drel. and Moringa oleifera Lam. on Salmonella typhi. Afr. J. Biotechnol. 6 (19): 2212-2215.

Elinge CM, Muhammad A, Atiku FA, Itodo AO, Peni IJ, Sanni OM, Mbongo AN (2012). Proximate, mineral and anti-nutrient composition of pumpkin (Cucurbita pepo L) seeds Extract. Int. J. Plant Res. 2 (5): 146-150.

Fanta (2010). The analysis of the nutrition situation in Uganda. Washington,.DC: Food and Nutrition Technical Assistance 11 Project (FANTA-2).

Fedha MS, Mwasaru MA, Njoroge CK, Ojijo NO, Ouma GO. (2010). Effect of drying on selected proximate composition of fresh and processed fruits and seeds of two pumpkin species. Agric. Biol. J. North Am. 1 (6): 1299-1302.

Fuglie LJ (2005). The moringa Tree: Moringa oleifera: Natural Nutrition for the Tropics. . Dakar, Senegal: Church World Service.

Gabriel-Ajobiewe, RAO, Cyril-Olutayo MC, Olumekun VO, Akinbileje FJ (2014). Effect of Bambusa tuldoides cv. ventricosa leaf extracted with fermented steep liquors of maize and sorghum on some pathogenic organisms. Malays. J. Microbiol. 10 (4): 280-289.

Gomiero L, Brown D, Zorzi D (2003). Extra value through quality management. Executive Outlook 3(1): 30-37.

Guslandi M (2005). Antibiotics for inflammatory bowel disease: do they work?. Eur. J. Gastroenterol. Hepatol. 17 (2): 145-147.

Harvey P, Rambeloson Z, Omar D (2010). The 2008 Uganda Food Consumption Survey: Determining the Dietary Patterns of Ugandan Women and Children. In A2Z; The USAID Micronutrient and Child Blindness Project, AED. Washington D.C, 2010.

Hossain M, Wahed MA, Ahmed S (2005). Increased food intake after the addition of amylase-rich flour to supplementary food for malnourished children in rural communities of Bangladesh. Food Nutr. Bull. 26(4): 323-329.

ljarotimi OS, Keshinro OO (2012). Formulation and nutritional quality of infant formula produced from germinated popcorn, Bambara groundnut and African locust bean flour. J. Microb. Biotechnol. Food Sci. 1 (6): 1358.

Jung S, Rickert DA, Deak NA, Aldin ED, Recknor J, Johnson LA, Murphy PA (2003). Comparison of Kjeldahl and Dumas methods for determining protein contents of soybean products. J. Am. Oil Chem. Soc. 80 (12): 1169-1173.

Lei V (2006). Probiotic potential of African fermented millet. Frederiksberg-Denmark. Food microbiology, Food Science, The Royal Veterinary and Agricultural University, Denmark. 
Lombor TT, Umoh EJ, Olakumi E (2009). Proximate Composition and Organoleptic Properties of Complementary Food Formulated from Millet (Pennisetum psychostachynum), Soyabeans (Glycine max) and Crayfish (Euastaeus spp). Pak. J. Nutr. 8 (10): 1676-1679.

Mbugua SK (1992). A method for the manufacture of a fermented cereal product. edited by 30.41991 and U.K Patent G.B 2.225 922B ARIPO Patent No. AP122, 20.6.1992. U.K.

Mohammad A (2004). Chemical Composition and Oil Characteristics of Pumpkin (Cucurbita maxima) seed kernals. Res. Bult. 129: 5-18.

Mouquet C, Greffeuille V, Treche S (2006). Characterization of the consistency of gruels consumed by infants in developing countries: assessment of the Bostwick consistometer and comparison with viscosity measurements and sensory perception. Int. J. Food Sci. Nutr. 57 (7-8):459-469.

Obilana AB (2003). Overview: Importance of Millets in Africa. AFRIPRO, Workshop on the Proteins of Sorghum and Millets: Enhancing Nutritional and Functional Properties for Africa Paper 02.

Odinakachukwu ICI, Nwosu N, Ngozi N, Ngozi I, Aloysius M (2014). Development and nutritional evaluation of infant complementary food from maize (Zea mays), soybean (Glycine max) and Moringa oleifera leaves. Int. J. Nutr. Food Sci. 3(4):290-299.

Ogbe AO, Affiku JH (2012). Proximate study, mineral and anti-nutrient composition of Moringa oleifera leaves harvested from Lafia, Nigeria: potential benefits in poultry nutrition and health. J. Microbiol. Biotechnol. Food Sci. 1(3):296-308.

Onyango C, Noetzold H, Ziems A, Hofmann T, Bley T, Henle T (2005). Digestibility and antinutrient properties of acidified and extruded maize-finger millet blend in the production of uji. LWT Food Sci. Technol. 38:697-707.

Papadopoulos MC, El Boushy AR, Roodbeen AE, Ketelaars EH (1986). Effects of processing time and moisture content on amino acid composition and nitrogen characteristics of feather meal. Anim. Feed Sci. Technol. 14(3):279-290.

Paragya S, Raghuvanshi RS (2012). Finger millet for food and nutritional security. Afr. J. Food Sci. 6 (4): 77-84.

Parvin R, Satter MA, Jabin SA, Abedin N, Islam F, Kamruzzaman M, Paul DK (2014). Studies on the development and evaluation of cereal based highly nutritive supplementary food for young. Int. J. Innov. Appl. Stud. 9 (2):974.
Patel JP, Gami B, Patel K, Solanki R (2011). Antibacterial activity of methanolic and acetone extract of some medicinal plants used in Indian folklore. Int. J. Phytomed. 3(2):261.

Ring U, DEVELO S (2009). MASINDI DISTRICT LOCAL GOVERNMENT. District environmental policy. Masindi.

Ruel M, Loechl C, Pelto G (2004). Donated fortified cereal blends improve the nutrient density of traditional complementary foods in Haiti but iron and zinc gaps remain for adults. Food Nutr. Bull. 25(4):361-373.

Sukhija PS, Palmquist DL (1988). Rapid method for determination of total fatty acid content and composition of feedstuffs and feces.J. Agric. Food Chem. 36(6):1202-1206.

Thierry NN, Tatsadjieu NL, Montet D, Mbofung CMF (2013). Effect of Pure Culture fermentation on biochemical composition of Moringa oleifera Lam leaves powders. Food Nutr. Sci. 4: 851-859.

Thurber MD, Fahey JW (2009). Adoption of Moringa oleifera to combat under-nutrition viewed through the lens of the "Diffusion of Innovations" theory. Ecol. Food Nutr. 48(3):212-225.

UBOS, ICF (2001). Uganda Demographic and Health Survey. Entebbe and ORC macro, Calverton, Maryland: USA.

UBOS, ICF (2012). Uganda Demographic and Health Survey, 2011. Kampala, Uganda: UBOS and Calverton, Maryland: ICF International Inc.

UNICEF (2012). WHOMorld Bank (2012). Levels And Trends In Child Malnutrition: UNICEF-WHO-The World Bank Joint Child Malnutrition Estimates." United Nations Children's Fund, World Health Organization and World Bank.

Usha R, Lakshmi M (2010). Nutritional, sensory and physical analysis of pumpkin flour incorporated into weaning mix. Malay. J. Nutr.16(3):379-387.

West KP Jr, Darnton-Hill I (2008). Vitamin A deficiency. In: Nutrition and Health: Nutrition and Health in Developing Countries, 2nd, Semba RD, Bloem MW (eds.). Humana Press, Totowa, NJ. pp. 377-433. 